\title{
Effect of deletion of the IpxM gene on virulence and vaccine potential of Yersinia pestis in mice
}

\section{Correspondence \\ Andrey P. Anisimov \\ anisimov@obolensk.org}

Received 8 August 2006

Accepted 12 December 2006

\author{
Andrey P. Anisimov, ${ }^{1}$ Rima Z. Shaikhutdinova, ${ }^{1}$ Lyudmila N. Pan'kina, ${ }^{2}$ \\ Valentina A. Feodorova, ${ }^{2}$ Elena P. Savostina, ${ }^{2}$ Ol'ga V. Bystrova, ${ }^{3}$ \\ Buko Lindner, ${ }^{4}$ Aleksandr N. Mokrievich, ${ }^{1}$ Irina V. Bakhteeva, ${ }^{1}$ \\ Galina M. Titareva, ${ }^{1}$ Svetlana V. Dentovskaya, ${ }^{1}$ Nina A. Kocharova, ${ }^{3}$ \\ Sof'ya N. Senchenkova, ${ }^{3}$ Otto Holst, ${ }^{4}$ Zurab L. Devdariani, ${ }^{2}$ Yuriy A. Popov, ${ }^{2}$ \\ Gerald B. Pier ${ }^{5}$ and Yuriy A. Knirel ${ }^{3}$

\footnotetext{
${ }^{1}$ State Research Center for Applied Microbiology and Biotechnology, Obolensk 142279, Moscow Region, Russia

${ }^{2}$ Russian Research Anti-Plague Institute 'Microbe', Saratov 410071, Russia

${ }^{3}$ N. D. Zelinsky Institute of Organic Chemistry, Russian Academy of Sciences, Moscow 119991 , Russia

${ }^{4}$ Research Center Borstel, Leibniz Center for Medicine and Biosciences, D-23845 Borstel, Germany

${ }^{5}$ Channing Laboratory, Brigham and Women's Hospital, Harvard Medical School, Boston MA 02115, USA
}

Yersinia pestis undergoes an obligate flea-rodent-flea enzootic life cycle. The rapidly fatal properties of $Y$. pestis are responsible for the organism's sustained survival in natural plague foci. Lipopolysaccharide (LPS) plays several roles in $Y$. pestis pathogenesis, prominent among them being resistance to host immune effectors and induction of a septic-shock state during the terminal phases of infection. LPS is acylated with 4-6 fatty acids, the number varying with growth temperature and affecting the molecule's toxic properties. $Y$. pestis mutants were constructed with a deletion insertion in the IpxM gene in both virulent and attenuated strains, preventing the organisms from synthesizing the most toxic hexa-acylated lipid A molecule when grown at $25{ }^{\circ} \mathrm{C}$ The virulence and/or protective potency of pathogenic and attenuated $Y$. pestis $\Delta / p x M$ mutants were then examined in a mouse model. The $\Delta / p x M$ mutation in a virulent strain led to no change in the $L_{50}$ value compared to that of the parental strain, while the $\Delta / p x M$ mutation in attenuated strains led to a modest 2.5-16-fold reduction in virulence. LPS preparations containing fully hexa-acylated lipid A were ten times more toxic in actinomycin D-treated mice then preparations lacking this lipid $\mathrm{A}$ isoform, although this was not significant $(P>0.05)$. The $\Delta / p x M$ mutation in vaccine strain $E V$ caused a significant increase in its protective potency. These studies suggest there is little impact from lipid A modifications on the virulence of $Y$. pestis strains but there are potential improvements in the protective properties in attenuated vaccine strains.

\section{INTRODUCTION}

Yersinia pestis survives within an enzootic cycle involving infection of susceptible rodent populations and transmission via flea vectors (Anisimov, 1999a, 2002a, b; Brubaker, 1991; Hinnebusch, 2003, 2004; Lorange et al., 2005; Perry, 2003; Perry \& Fetherston, 1997). To maintain this cycle, $Y$. pestis must first cause a sustained and high-level bacteraemia

Abbreviations: $\mathrm{Cl}, 95 \%$ confidence interval; ESI FT-ICR, electrospray ionization Fourier transform ion cyclotron resonance; $I m D_{50}, 50 \%$ immunizing dose; $L A_{\text {hexar }}$, hexa-acyl lipid $A ; A_{\text {tetra, }}$ tetra-acyl lipid $A ; L P S$, lipopolysaccharide. in rodents that is sufficient to transfer the microbe to fleas following a blood meal (Anisimov, 1999a, 2002a; Brubaker, 1991; Feodorova \& Golova, 2005; Hinnebusch, 2004; Lorange et al., 2005; Perry \& Fetherston, 1997). Next, $Y$. pestis must colonize the flea's alimentary canal producing a bacterial biofilm that blocks the proventriculus, the organ that connects the flea's oesophagus to its midgut. This blockage prevents the flea from taking a blood meal and forces it to bite a warm-blooded host repeatedly in a futile attempt to feed. At this stage, regurgitated bacteria enter the skin tissues at the site of the flea bite (Anisimov, 1999a, 2002a; Brubaker, 1991; Hinnebusch, 2003, 2004; 
Lorange et al., 2005; Perry, 2003; Perry \& Fetherston, 1997). The bacteraemia caused by $Y$. pestis results from its impressive ability to overcome mammalian host defences and overwhelm hosts with massive growth (Anisimov, 2002a, b; Brubaker, 1991; Feodorova \& Golova, 2005; Hinnebusch, 2004; Lorange et al., 2005; Perry \& Fetherston, 1997). Usually the bacteraemic phase evolves into lethal septic shock and the host's death forcing fleas to depart to feed on a new rodent, which subsequently becomes infected (Anisimov, 1999a, 2002a, b; Brubaker, 1991; Butler, 1989).

The triggering event of septic shock caused by Gramnegative bacteria is most likely the release of lipopolysaccharide (LPS). Lipid A, the toxic portion of the LPS molecule, causes the release of numerous host proinflammatory cytokines, and activates the complement cascade and the coagulation cascade. Recent studies suggest that Toll-like receptors, inflammatory cytokines, eicosanoids, free radicals, macrophage migration inhibitory factor, signal protein kinases and transcription factors all play an important part in the pathobiology of Gram-negativemediated septic shock (Das, 2000; van Amersfoort et al., 2003). Y. pestis LPS has no repeating O-antigen-like polysaccharide but is composed of lipid A and a temperaturedependent variable oligosaccharide analogous to the inner and outer core of enterobacterial LPS (Gremyakova et al., 2003; Hitchen et al., 2002; Kawahara et al., 2002; Knirel et al., 2005a, b; Prior et al., 2001; Rebeil et al., 2004; Vinogradov et al., 2002). As it was shown for prototypic lipid A from Escherichia coli, its characteristic structural features, especially its two acyloxyacyl moieties and its two phosphate groups, are needed to trigger the endotoxin response in mammalian cells (Alexander \& Rietschel, 2001; Rietschel et al., 1994). Recently it was shown that in $Y$. pestis the increase from flea temperature $\left(21-28{ }^{\circ} \mathrm{C}\right)$ to the host temperature $\left(37{ }^{\circ} \mathrm{C}\right)$ caused a reduction of the immunostimulatory/endotoxic activity of LPS (Kawahara et al., 2002; Rebeil et al., 2004; Tynianova et al., 2003) and a subsequent decrease of the degree of acylation of the lipid A from six to four fatty-lipid residues (Kawahara et al., 2002; Knirel et al., 2005a; Rebeil et al., 2004).

lpxM (alternatively $m s b B$ or waaN) (Reeves et al., 1996) is involved in the biosynthesis of lipid A. LpxM is a latefunctioning acyltransferase for myristate $\left(C_{14}\right)$, which functions optimally after laurate $\left(\mathrm{C}_{12}\right)$ incorporation by LpxL (alternatively HtrB or WaaM) (Reeves et al., 1996) onto the E. coli $\mathrm{KDO}_{2}$-lipid $\mathrm{IV}_{\mathrm{A}}$ (2-keto-3-deoxyoctulosonic acid) structure (Clementz et al., 1997; Raetz \& Whitfield, 2002). Both LpxL and LpxM are the KDO-dependent acyltransferases responsible for the addition of a secondary acyl substitution on the lipid A portion of LPS (Brozek \& Raetz, 1990; Clementz et al., 1997; Nichols et al., 1997; Raetz \& Whitfield, 2002; Sunshine et al., 1997). LPS isolated from $\Delta l p x M$ knockout mutants contains penta-acylated lipid $A$ and $E$. coli $\Delta l p x M$ viable cells or purified LPS from this mutant had a 100010000 -fold reduction in the ability to stimulate E-selectin production by human endothelial cells and TNF- $\alpha$ production by adherent monocytes when compared with parent bacteria harbouring hexa-acylated lipid A (Somerville et al., 1996). Recently it was shown that the Y. pestis lpxM (Dentovskaya et al., 2006; Rebeil et al., 2006) and $l p x P$ (Rebeil et al., 2006) homologues encode the acyltransferases that add $\mathrm{C}_{12}$ and $\mathrm{C}_{16: 1}$ groups, respectively, to lipid $\mathrm{IV}_{\mathrm{A}}$ to generate the hexa-acylated form, and that their expression is upregulated at $21{ }^{\circ} \mathrm{C}$ in vitro and in the flea midgut (Rebeil et al., 2006).

Recently it was shown that although LPSs from $\Delta l p x M$ mutants had decreased endotoxic activity, they were still as potent adjuvants of the immune response as hexa-acylated molecules from the parent strains (Steeghs et al., 1999; van der Ley et al., 2001) due to the equal ability of the hexa- and penta-acylated forms to upregulate surface molecule expression on dendritic cells and stimulate T-cells (Kalupahana et al., 2003). Thus, a penta-acylated LPS isolated from a $\Delta l p x L 1$ mutant of Neisseria meningitidis had decreased endotoxic activity but was still a potent adjuvant for immune responses (van der Ley et al., 2001). These findings suggest that a $Y$. pestis $\Delta l p x M$ mutant also may be less virulent but may be useful for the development of new vaccines.

In this study, we investigated the effects of variations in the lipid A structure on the endotoxic activity of the LPS and on the pathogenicity of $Y$. pestis strains that differ in their initial virulence potential. To perform these investigations, we created $\Delta l p x M$ mutants in wild-type strain 231 as well as in attenuated strains, including the Russian vaccine strain, $\mathrm{EV}$, line NIIEG. We also investigated the effect of a $\Delta l p x M$ mutation on the vaccine properties of strain EV. This mutation resulted in an inability to synthesize the hexa-acyl lipid A ( $\left.\mathrm{LA}_{\text {hexa }}\right)$ structure found in the parental strains when organisms are grown at $25{ }^{\circ} \mathrm{C}$. Overall, we found a tenfold increase in the $\mathrm{LD}_{50}$ of the LPS from the $\Delta l_{p x M}$ mutant, but this was not significant at $P>0.05$. Inability of the virulent $Y$. pestis $231 \Delta l p x M$ mutant to produce a hexa-acylated LPS did not change its ability to cause a lethal infection, while in the attenuated strains there was a modest reduction in virulence. Of note, in the vaccine strain, there was improved protective efficacy and decreased reactogenicity following immunization with the $\Delta l p x M$ mutant.

\section{METHODS}

Bacterial strains, plasmids and primers. The characteristics of the $Y$. pestis and E. coli strains used in this study are given in Table 1. Y. pestis strains were obtained from the Russian Anti-Plague Research Institute 'Microbe' (Russia) and were used in our previous studies as representatives of different biovars (Anisimov et al., 2005; Knirel et al., 2005a, b). Bacterial cultures were started from lyophilized stocks. For LPS isolation and structural analysis, to guarantee the safety of the investigators, $Y$. pestis strain 231 was cured of the pCD virulence plasmid by selection at $37{ }^{\circ} \mathrm{C}$ on magnesium oxalate agar plates (Higuchi \& Smith, 1961). The variant was completely avirulent in mice at $10^{8}$ organisms by the parenteral route. None of the absent plasmids (pFra, pCD, pPst) or missing parts of the genome $(\Delta p g m)$ of 
Table 1. Bacterial strains used in this study

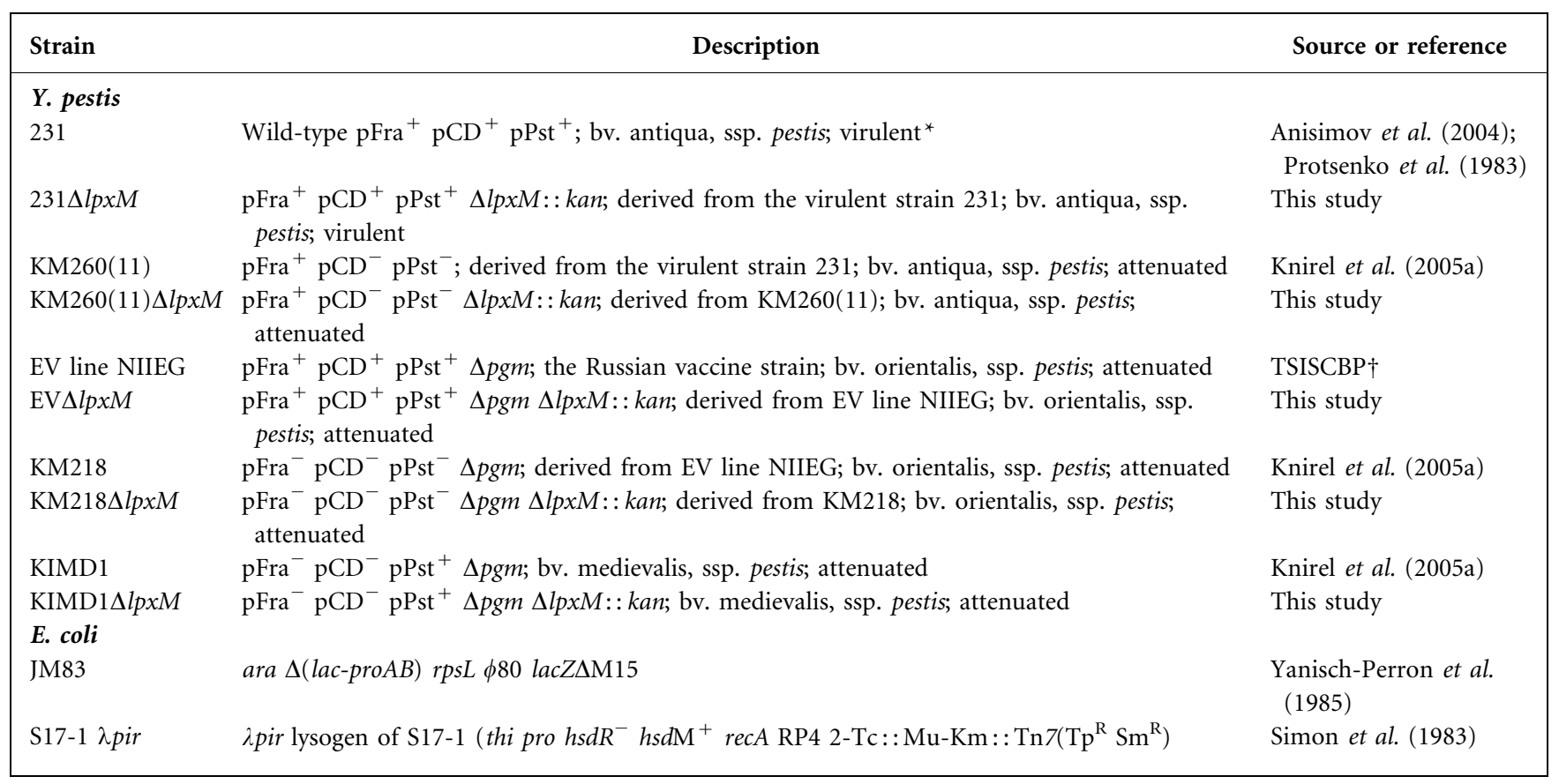

${ }^{*}$ For more detailed information on biovar-subspecies interrelations see Anisimov et al. (2004).

$\dagger$ Tarasevich State Institute for Standardization and Control of Biomedical Preparations, Sivtsev Vrazhek 41, Moscow 121002, Russia.

the mutant strains contained genes for LPS biogenesis, and did not exert influence on LPS structure when compared with the 'wild-type' in any of the strains (Hitchen et al., 2002; Kawahara et al., 2002; Knirel et al., 2005a; Rebeil et al., 2004) except for specially generated mutants $(\Delta l p x M$ mutants in this study). Plasmids and primers used are listed in Tables 2 and 3.

Medium and culture conditions. E. coli strains were routinely grown on Luria-Bertani (LB) agar or in LB broth (Miller, 1972) at $37^{\circ} \mathrm{C}$. For mutagenesis or virulence experiments, cultures of $Y$. pestis were grown at $25{ }^{\circ} \mathrm{C}$ in brain heart infusion (BHI) (Difco Laboratories) broth or on BHI agar. BHI agar with $5 \%$ sucrose was used for the selection of $Y$. pestis double recombinants. For LPS isolation, Y. pestis strains were grown at $25{ }^{\circ} \mathrm{C}$ in New Brunswick Scientific fermenters with working volumes up to $10 \mathrm{l}$. Liquid aerated media was used and composed of fish-flour hydrolysate $\left(20-30 \mathrm{~g} \mathrm{l}^{-1}\right)$, yeast autolysate $\left(10 \mathrm{~g} \mathrm{l}^{-1}\right)$, glucose $\left(3-9 \mathrm{~g} \mathrm{l}^{-1}\right), \mathrm{K}_{2} \mathrm{HPO}_{4}\left(6 \mathrm{~g} \mathrm{l}^{-1}\right), \mathrm{KH}_{2} \mathrm{PO}_{4}\left(3 \mathrm{~g} \mathrm{l}^{-1}\right)$ and $\mathrm{MgSO}_{4}$ $\left(0.5 \mathrm{~g} \mathrm{l}^{-1}\right), \mathrm{pH}$ 6.9-7.1. $\mathrm{pH}$ and $\mathrm{pO}_{2}$ control was used with the specified $\mathrm{pO}_{2}$ value $>10 \%$. The $Y$. pestis cellular biomasses were harvested by centrifugation, after $48 \mathrm{~h}$ of incubation, and then freezedried. Growth media were supplemented, as needed, with ampicillin $\left(50 \mu \mathrm{g} \mathrm{ml}^{-1}\right)$, kanamycin $\left(20 \mu \mathrm{g} \mathrm{ml}^{-1}\right)$ or polymyxin B $\left(100 \mu \mathrm{g} \mathrm{ml}^{-1}\right)$.

Mutagenesis. A region 1529 bp 5' (designated left shoulder) and a region $1500 \mathrm{bp} \mathrm{3}$ ' (designated right shoulder) of the lp $x M$ gene, including the first 180 nucleotides and the last 194 nucleotides, respectively (Table 3), were amplified by PCR with the use of a DNA template obtained from strain 231. The primers for the left shoulder, msb5S1.5 and msb3X, contained SacI and XbaI restriction sites, respectively. The primers for the right shoulder, $\mathrm{msb5H}$ and msb3S1.5, contained HindIII and SacI restriction sites, respectively (Table 3). To create the $\Delta l p x M$ mutants, the amplified left and right shoulders of the $Y$. pestis lp $x M$ gene were gel purified, and cloned into the pBluescript SK $(-)$ vector (Stratagene) within appropriate restriction sites. The resulting recombinant plasmids, pBsLS and pBsRS, respectively, were used to transform E. coli JM83 by electroporation. The cloned fragments of $Y$. pestis lpxM gene were then isolated following digestion with SacI and HindIII and electrophoresis in a $0.9 \%$ agarose gel. After that, they were assembled within the pUC19 vector digested with SacI. The resulting recombinant plasmid, pUCLR, was used to transform E. coli JM83 by electroporation. This fragment, containing left and right shoulders of the lpxM gene with the polylinker XbaI-HindIII region from pBluescript SK $(-)$ between them, was removed by digestion with $S a c I$ and recloned within the SacI site of the pCVD442 suicide vector. The resulting recombinant plasmid, pMSB8, was used to transform E. coli S17-1 $\lambda$ pir by electroporation. A 1264 bp Bam HI fragment from pUC4K containing the $\mathrm{Km}^{\mathrm{R}}$ gene was inserted in the BcuI site at blunted ends in place of the deleted fragment of the $l p x M$ gene (between the amplified shoulders of the lp $x M$ gene). The resulting recombinant plasmid, pMSB3K, containing the indicated $5^{\prime}$ and $3^{\prime}$ flanking regions of the $l p x M$ gene from $Y$. pestis 231 with a $0.59 \mathrm{~kb}$ deletion replaced by the $\mathrm{Km}^{\mathrm{R}}$ locus from pUC4K, was electroporated into E. coli S17-1 $\lambda$ pir.

The pMSB3K plasmid was introduced into $Y$. pestis strains by conjugation using polymyxin for counter-selection, the $\mathrm{Km}^{\mathrm{R}} \mathrm{Ap}^{\mathrm{R}}$ exoconjugants were then counter-selected by growing on plates containing $5 \%$ sucrose, and the $\mathrm{Km}^{\mathrm{R}} \mathrm{Ap}^{\mathrm{S}}$ colonies in which allelic exchange had occurred were selected and deletion of the chromosomal lpxM gene confirmed by PCR (Donnenberg \& Kaper, 1991).

Isolation of LPS and SDS-PAGE. LPSs were extracted from dried cells with phenol/chloroform/light petroleum ether (Galanos et al., 1969) and purified by repeated ultracentrifugation (105 $000 \mathrm{~g}, 4 \mathrm{~h})$, following enzymic digestion of nucleic acids and proteins. The purity of the isolated LPS preparations was evident from the lack of protein and nucleic acid contaminants as determined by SDS-glycine PAGE with silver staining of the gels (Prior et al., 2001). The LPS preparations from the $Y$. pestis KM218 parental and KM218 $l p x M$ mutant strains were designated LPS $S_{\text {parent }}$ and $\mathrm{LPS}_{\Delta \mathrm{lpxM}}$, respectively. 
Table 2. Plasmids used in this study

\begin{tabular}{|c|c|c|c|c|}
\hline Plasmid & Description & Purpose & $\begin{array}{l}\text { Antibiotic } \\
\text { resistance }\end{array}$ & $\begin{array}{l}\text { Source or } \\
\text { reference }\end{array}$ \\
\hline pBluescript SK $(-)$ & High-copy-number cloning vector & Initial subcloning & $A p^{R}$ & Stratagene \\
\hline pBsLS & $\begin{array}{l}\text { A } 1.5 \mathrm{~kb} \text { SacI-XbaI fragment containing left shoulder } \\
\text { of } l p x M \text { in pBluescript SK (-) }\end{array}$ & Source of the left shoulder of $l_{p} x M$ & $\mathrm{Ap}^{\mathrm{R}}$ & This study \\
\hline pBsRS & $\begin{array}{l}\text { A } 1.5 \mathrm{~kb} \text { HindIII-SacI fragment containing right } \\
\text { shoulder of } l_{p} x M \text { in pBluescript SK }(-)\end{array}$ & $\begin{array}{l}\text { Source of the right shoulder of } \\
\text { lpxM }\end{array}$ & $A p^{R}$ & This study \\
\hline pUC19 & High-copy-number cloning vector & $\begin{array}{l}\text { Subcloning of the both shoulders } \\
\text { of } l p x M\end{array}$ & $\mathrm{Ap}^{\mathrm{R}}$ & $\begin{array}{l}\text { GenBank } \\
\text { no. M77789 }\end{array}$ \\
\hline pUCLR & $\begin{array}{l}\text { A } 1.5 \mathrm{~kb} \text { SacI-XbaI fragment from pBsLS containing } \\
\text { left shoulder of } l p x M \text { and } X b a \mathrm{I}-H i n \mathrm{dIII} \text { fragment of } \\
\text { polylinker from pBluescript SK }(-)+\text { a } 1.5 \mathrm{~kb} \\
\text { HindIII-SacI fragment from pBsRS containing right } \\
\text { shoulder of } l p x M \text { in pUC19 digested with } S a c \mathrm{I}\end{array}$ & $\begin{array}{l}\text { Source of the both shoulders of } \\
\operatorname{lp} x M\end{array}$ & $\mathrm{Ap}^{\mathrm{R}}$ & This study \\
\hline pCVD442 & Suicide vector, $s a c B$, mob & Suicide vector & $\mathrm{Ap}^{\mathrm{R}}$ & $\begin{array}{r}\text { Donnenberg \& } \\
\text { Kaper (1991) }\end{array}$ \\
\hline pMSB8 & $\begin{array}{l}\text { A } 3.0 \mathrm{~kb} \text { SacI fragment from pUCLR containing left } \\
\text { and right shoulders of } l_{p} \times M \text { separated by } X b a \mathrm{I}- \\
\text { HindIII fragment of polylinker from pBluescript } \\
\text { SK (-) in pCVD442 }\end{array}$ & Subcloning into suicide vector & $\mathrm{Ap}^{\mathrm{R}}$ & This study \\
\hline pUC4K & Cloning vector, linker and kanamycin region & Source of $\mathrm{Km}^{\mathrm{R}}$ cassette & $\mathrm{Ap}^{\mathrm{R}} \mathrm{Km}^{\mathrm{R}}$ & $\begin{array}{l}\text { GenBank no. } \\
\text { X06404 }\end{array}$ \\
\hline pMSB3K & $\begin{array}{l}\text { A } 1.3 \mathrm{~kb} \text { Bam HI fragment from pUC4K containing } \\
\text { the } \mathrm{Km}^{\mathrm{R}} \text { gene in pMSB8 }\end{array}$ & $\begin{array}{l}\text { Subcloning into suicide vector for } \\
\text { conjugation }\end{array}$ & $\mathrm{Ap}^{\mathrm{R}} \mathrm{Km}^{\mathrm{R}}$ & This study \\
\hline
\end{tabular}

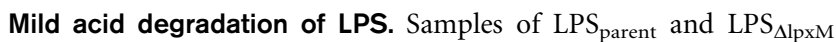
were degraded with aqueous $2 \%$ acetic acid at $100{ }^{\circ} \mathrm{C}$ for $4 \mathrm{~h}$. The water-insoluble lipid precipitate (crude lipid A) from each sample was separated by centrifugation $(12000 \mathrm{~g}, 15 \mathrm{~min})$, washed and resuspended in water, lyophilized and the solid preparation then treated with a chloroform/methanol mixture $(1: 1, \mathrm{v} / \mathrm{v})$, which extracts contaminating phospholipids from lipid A. The water-soluble supernatant was fractionated by gel-permeation chromatography on a column $(70 \times 2.6 \mathrm{~cm})$ of Sephadex G-50 (S) (Amersham Biosciences) using aqueous $1 \%$ aqueous acetic acid supplemented with $0.4 \%$ pyridine as eluant. Monitoring was performed with a differential refractometer (Knauer). Fractions that contained core-like oligosaccharides were collected and lyophilized.

Mass spectrometry. High-resolution electrospray ionization Fourier transform ion cyclotron resonance (ESI FT-ICR) MS was performed in the negative ion mode using an Apex II instrument (Bruker Daltonics) equipped with a $7 \mathrm{~T}$ actively shielded magnet and an Apollo electrospray ion source as described previously (Knirel et al., 2005a). Samples were dissolved at a concentration of $\sim 10 \mathrm{ng} \mu \mathrm{l}^{-1}$ in a $50: 50: 0.001$ (by vol.) mixture of 2-propanol/water/triethylamine, and sprayed at a flow rate of $2 \mu \mathrm{min}^{-1}$. Capillary entrance voltage was set to $3.8 \mathrm{kV}$, and dry gas temperature to $150^{\circ} \mathrm{C}$. The spectra were charge deconvoluted, and mass numbers given refer to the monoisotopic molecular masses.

Animals. Outbred Swiss Webster mice weighing approximately $20 \mathrm{~g}$ were used in animal experiments that were approved by the ethical committee of the State Research Center for Applied Microbiology and Biotechnology. Animals were kept in cages in groups of four to eight, and allowed to feed and drink ad libitum. Median lethal doses $\left(\mathrm{LD}_{50}\right)$, $50 \%$ immunizing doses $\left(\mathrm{ImD}_{50}\right)$ and $95 \%$ confidence intervals $(\mathrm{CI})$ were measured according to the method of Kärber (Ashmarin \& Vorob'ov, 1962).

Testing the toxicity of LPS and the lethality of $Y$. pestis strains in mice. Actinomycin D-sensitized or naïve mice were used in our experiments to derive the $\mathrm{LD}_{50}$ values of LPS preparations and $Y$.

Table 3. Oligonucleotide primers used to amplify the $5^{\prime}$ and $3^{\prime}$ flanking regions of the $I p x M$ gene

\begin{tabular}{|c|c|c|c|c|c|}
\hline Gene amplified & Location $(\mathbf{b p})^{\star}$ & Size $(\mathbf{b p})$ & Product size $(b p)$ & Primer & Sequence $\left(5^{\prime}\right.$ to $\left.3^{\prime}\right)$ and restriction site $\dagger$ \\
\hline \multicolumn{6}{|l|}{ Left shoulder } \\
\hline $\operatorname{lp} x M$ & $2340356-2340384$ & 29 & & msb5S1.5 & ATGAGAGCTCCACCAAAGATGCCAATGAC, SacI \\
\hline$l p x M$ & $2341864-2341837$ & 28 & 1529 & $\operatorname{msb3X}$ & GGGCTCTAGAAGCAAATTTCCCAGCGAG, XbaI \\
\hline \multicolumn{6}{|l|}{ Right shoulder } \\
\hline$l p x M$ & $2342452-2342483$ & 32 & & $\mathrm{msb} 5 \mathrm{H}$ & TTATAAGCTTCATCGTCTTGATATCTATATCC, HindIII \\
\hline$l p \times M$ & $2343952-2343924$ & 29 & 1500 & msb3S1.5 & AACAGAGCTCGCATCAACAAGTTAGGTGG, SacI \\
\hline
\end{tabular}

${ }^{\star}$ Relative to genome of $Y$. pestis CO92 (Parkhill et al., 2001).

$\dagger$ Recognition sites for restriction endonucleases are underlined, and the restriction endonucleases indicated. 
pestis attenuated strains under study. A total of $5 \mu \mathrm{g}$ actinomycin D (AppliChem) in a total volume of $200 \mu \mathrm{l}$ pyrogen-free $0.9 \% \mathrm{NaCl}$ solution was intraperitoneally injected into groups with 8 mice each along with tenfold dilutions of LPS preparations, or along with organisms obtained from cultures grown for $48 \mathrm{~h}$ at $25{ }^{\circ} \mathrm{C}(120$ mice, divided into 30 groups of 4 ). Four groups of naïve mice ( 80 mice, divided into 20 groups of 4 ) were challenged subcutaneously (using tenfold dilutions) with suspensions of bacteria in $0.9 \% \mathrm{NaCl}$ solution in a total volume of $0.2 \mathrm{ml}$. Mortality due to LPS toxicity was recorded up to 7 days post injection, while animals infected with $Y$. pestis cultures were observed for a period of 21 days. Animals that succumbed to infection were dissected and bacterial cultures obtained to confirm systemic spread of $Y$. pestis.

Immunization and challenge. Bacterial cultures of either the EV line NIIEG strain or the EVAlpxM mutant were grown for $48 \mathrm{~h}$ at $25^{\circ} \mathrm{C}$ and administered subcutaneously in a total volume of $0.2 \mathrm{ml} 0.9 \%$ $\mathrm{NaCl}$ solution (with tenfold dilutions from $10^{9}$ to $10^{5}$ c.f.u.) as a single injection on day 0 (70 mice, divided into 10 groups of 7). Two groups of seven mice were treated only with $0.9 \% \mathrm{NaCl}$ solution. At day 21 post-immunization the mice were challenged subcutaneously with $3.5 \times 10^{4} \mathrm{LD}_{50}\left(2.1 \times 10^{5}\right.$ c.f.u. $)$ of $Y$. pestis strain 231 . The two control groups of naïve animals were challenged subcutaneously with $3.5 \times 10^{4} \mathrm{LD}_{50}\left(2.1 \times 10^{5}\right.$ c.f.u. $)$ or $17 \mathrm{LD}_{50}\left(10^{2}\right.$ c.f.u. $)$ of the same strain. The survival of mice was monitored daily for 21 days. The degree of protection offered by the vaccines was assessed by measuring the shift in the $\mathrm{ImD}_{50}$ values in the immunized animals.

\section{RESULTS}

\section{Isolation and SDS-PAGE characterization of the LPSs}

Each $Y$. pestis strain was grown at $25{ }^{\circ} \mathrm{C}$ and the corresponding LPS samples were isolated by phenol/chloroform/ light petroleum extraction and fractionated by SDS-PAGE. Examples of LPS migration for two pairs of isogenic strains are shown in Fig. 1. LPS preparations from the $\Delta l p x M$ mutants migrated through the gel slightly faster and as more compact bands than those from the parent strains, suggesting that LPS molecules from the wild-type strains are, on average, larger.

\section{Structural studies of the LPSs}

LPS $_{\text {parent }}$ and $\mathrm{LPS}_{\triangle l p x M}$ from $Y$. pestis KM218 and KM260(11) were degraded under mild acid conditions to cleave the linkage between the core and lipid A. The isolated and purified lipid A and core oligosaccharide, as well as the whole LPS samples, were studied by ESI FT-ICR MS. The mass spectrum of the lipid A sample from $Y$. pestis KM218 LPS parent (Fig. 2a) showed the predominance of tetra-acyl and hexa-acyl variants, whose structures have been determined previously (Aussel et al., 2000; Knirel et al., 2005a). LA hexa includes four primary 3-hydroxymyristoyl groups (3OH14:0) and two secondary acyl groups, one dodecanoyl $(12: 0)$ and one palmitoleoyl $(16: 1)$; tetra-acyl lipid A $\left(\mathrm{LA}_{\text {tetra }}\right)$ is devoid of both secondary fatty acids, and minor penta-acyl lipid $\mathrm{A}$ variants $\left(\mathrm{LA} 1_{\text {penta }}\right.$ and LA2 $2_{\text {penta }}$ ) lack either of them (Fig. 2e). Lipid A from $Y$.

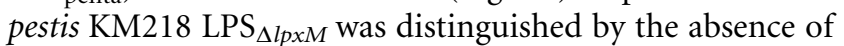

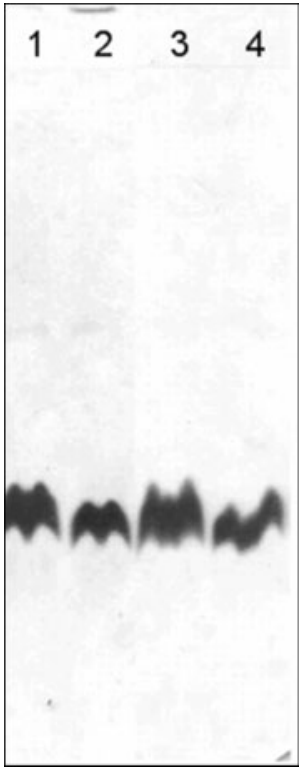

Fig. 1. Silver-stained SDS-PAGE gel of LPS samples from $Y$. pestis strains grown at $25{ }^{\circ} \mathrm{C}$. $Y$. pestis samples $(2.5 \mu \mathrm{g})$ were applied to the gel. Distinctions between the mobility of the LPS samples are seen most clearly when the upper confines of the bands are compared. Lane 1, KM218; lane 2, KM218 $\Delta / p x M$; lane 3, KIMD1; lane 4, KIMD1 $1 / p x M$.

$\mathrm{LA}_{\text {hexa }}$ and $\mathrm{LA} 1_{\text {penta }}$, i.e. the structural variants that include the $12: 0$ group (Fig. 2b). Instead, a significant increase in the content of LA2 $2_{\text {penta }}$ with the single $16: 1$ secondary group was observed. Essentially the same structural variants were found when the mass spectra of the lipid A samples from $Y$. pestis KM260(11) LPS ${ }_{\text {parent }}$ and $\mathrm{LPS}_{\Delta l p x M}$ were compared (Fig. 2c, d, respectively).

No significant changes in the core composition and the content of the cationic sugar, 4-amino-4-deoxy-L-arabinose $\left(\right.$ Ara4N), were observed in $\mathrm{LPS}_{\text {parent }}$ and $\mathrm{LPS}_{\triangle l p x M}$ from both strains studied (data not shown). Therefore, our data confirmed the finding of Rebeil et al. (2006) that Y. pestis $\Delta l_{p} \times M$ mutants are unable to incorporate the dodecanoyl group into lipid A and showed that the other LPS biosynthesis pathways are unaffected by the mutation.

\section{Toxicity of LPSs in actinomycin D-sensitized mice}

Several substances (Galanos et al., 1979; Seyberth et al., 1972), including actinomycin D (Brown \& Morrison, 1982; Seyberth et al., 1972), when administered in sublethal amounts, have been documented to enhance by more than 1000 -fold the sensitivity of mice to the lethal effect of LPS. Although the mechanisms of sensitization by these metabolic inhibitors have not been elucidated in detail, blocking of protein synthesis by inhibition of RNA synthesis may be involved. All animals challenged only with LPS-free actinomycin D solutions survived. All of the 

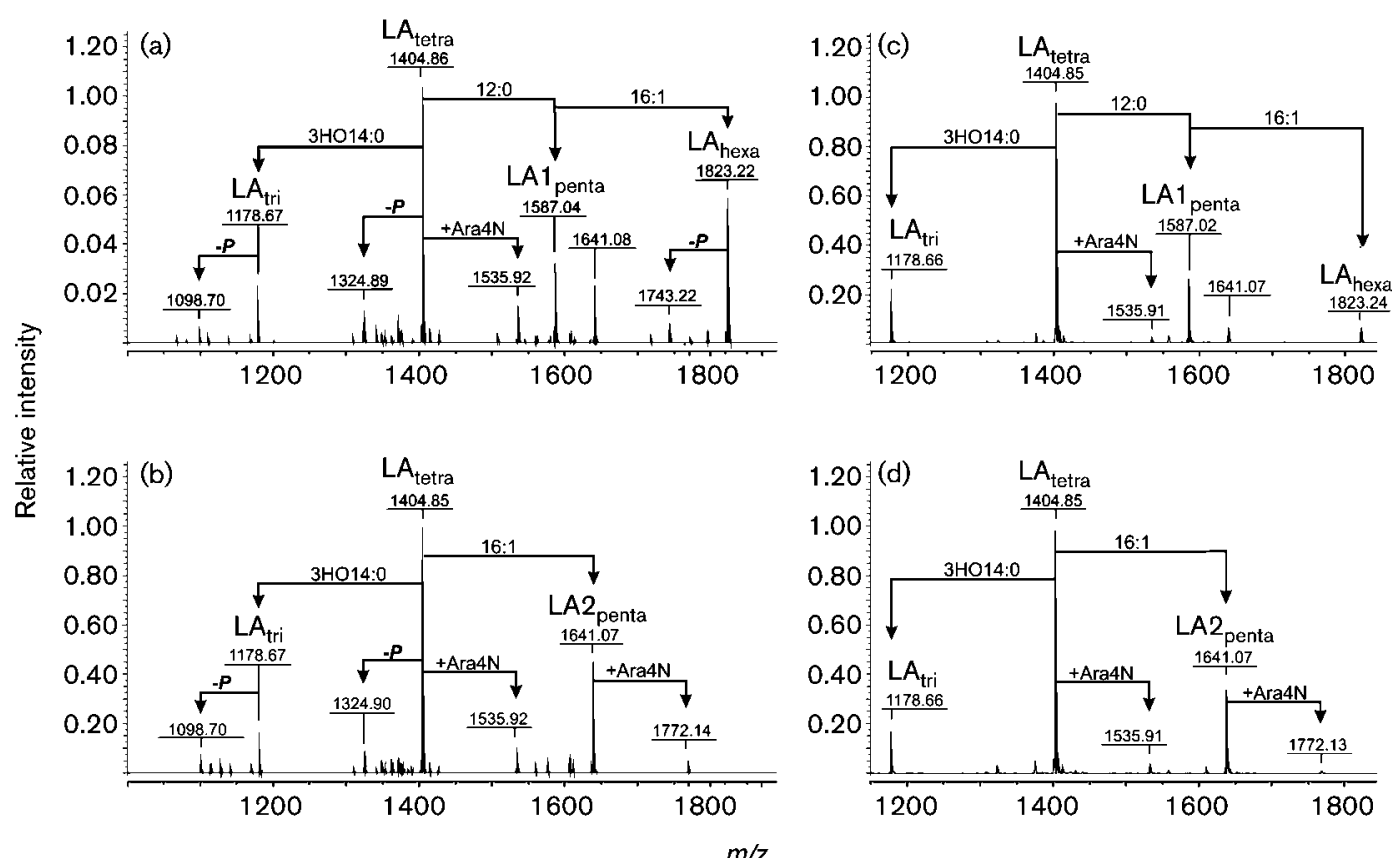

(e)
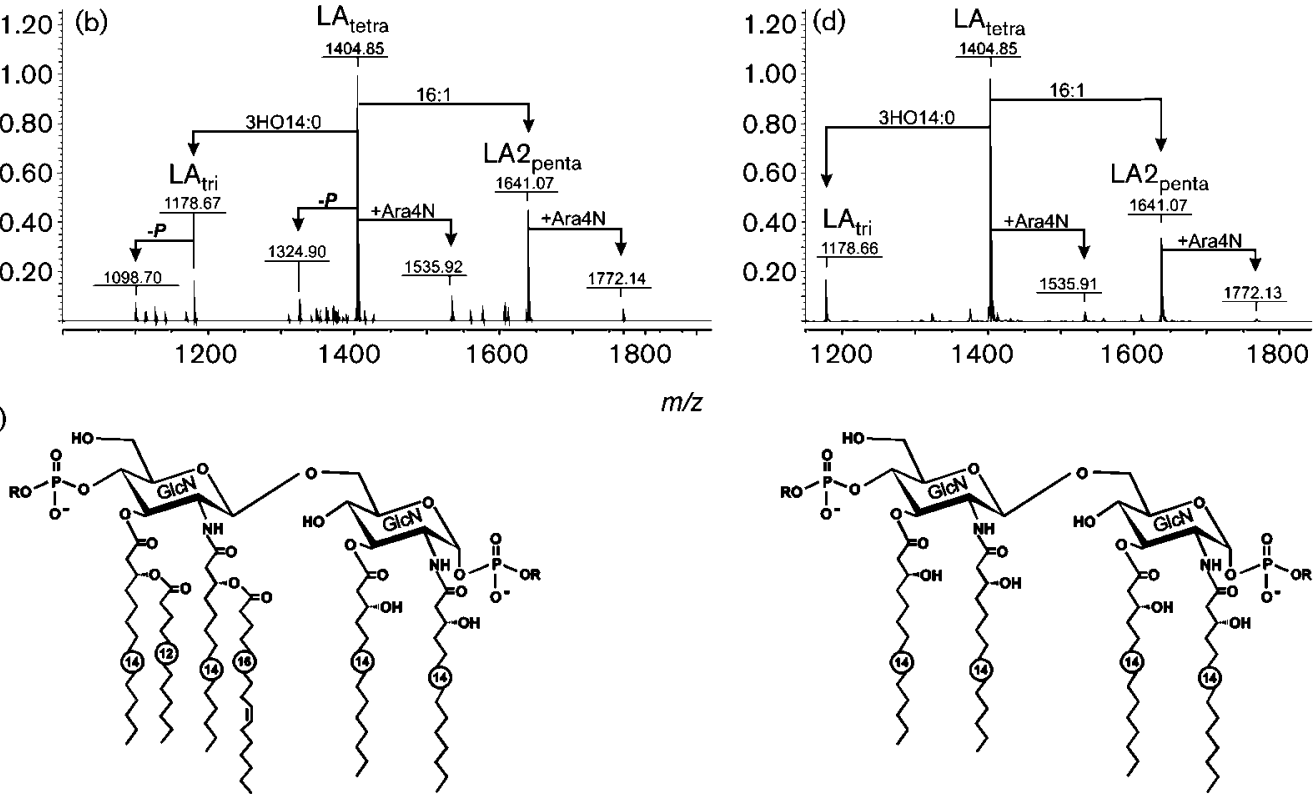

$m / z$

LA $A_{\text {hexa }}$

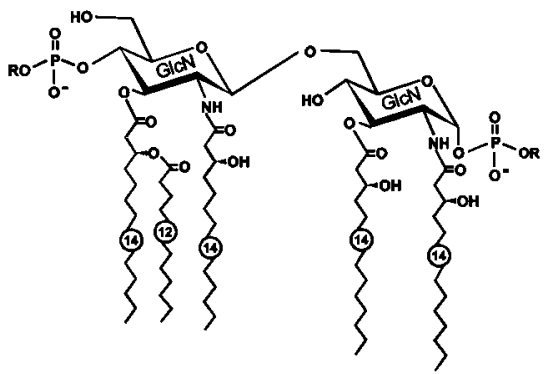

LA1 $1_{\text {penta }}$

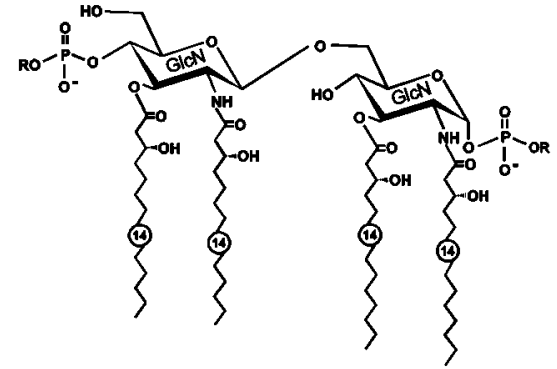

$\mathbf{L A}_{\text {tetra }}$

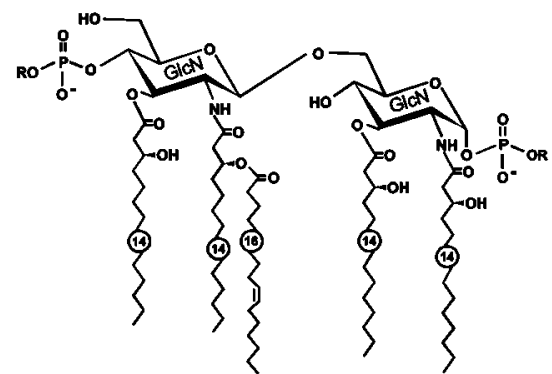

$L A 2_{\text {penta }}$

Fig. 2. Charge deconvoluted negative ion ESI FT-ICR mass spectra of lipid A samples from $Y$. pestis KM218 LPS parent $(a)$,

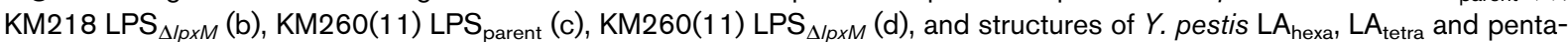
acyl lipid $A$ variants $\left(L A 1_{\text {penta }}\right.$ and $\left.L A 2_{\text {penta }}\right)(\mathrm{e})$. In the $\Delta / p x M$ mutants $(b, d)$ no $L A_{\text {hexa }}$ nor $L A 1_{\text {penta }}$ are detected. Ara4N, 4Amino-4-deoxyarabinose. Numbers inside circles refer to numbers of carbons in fatty acids.

animals injected with LPS that died succumbed to endotoxic shock within 2 days of injection. The toxicity of the LPS preparation from the Y. pestis strain KM218
$\left[\mathrm{LD}_{50}=5 \mu \mathrm{g}\right.$ per animal $(95 \% \mathrm{CI}=1-21 \mu \mathrm{g}$ per animal $\left.)\right]$ was ten times as large as that from the $\Delta l p x M$ mutant $\left[\mathrm{LD}_{50}=53 \mu \mathrm{g}\right.$ per animal $(95 \% \mathrm{CI}=13-337 \mu \mathrm{g}$ per 
animal)], but with the overlapping $95 \% \mathrm{CI}$ the differences in $\mathrm{LD}_{50}$ were not significant at $P>0.05$.

\section{Affect of the deletion of IpXM on the lethality of virulent and attenuated $Y$. pestis strains in a murine system}

The $Y$. pestis parental and $\Delta l p x M$ strains were used to assess the contribution to virulence made by having the genetic ability to synthesize a $\mathrm{LA}_{\text {hexa }}$. There was no effect on virulence of the $Y$. pestis wild-type strain 231 due to deletion of lpxM (Table 4).

When attenuated strains (i.e. lacking the pCD plasmid or with further mutations) of $Y$. pestis are injected into mice, the residual virulence can be evaluated with either the use of very high infective doses or immunocompromised animals treated with immunosuppressants (Anisimov, 2002a; Brygoo \& Rajenison, 1973; Jackson \& Burrows, 1956; Vasil'eva et al., 1988). In experiments with attenuated strains, the use of both approaches indicated that $\Delta l_{p} \times M$ mutation resulted in a $2.5-16$-fold reduction in virulence as measured by an increase in $\mathrm{LD}_{50}$ (Table 4 ). The overlap in the $95 \% \mathrm{CI}$ for the $\mathrm{LD}_{50}$ for wild-type, and lpxMdeleted strains EV and KM218 indicated the increase in $\mathrm{LD}_{50}$ was not significant at $P>0.05$, but the one $\log$ increase in virulence for strain KIMD1 was significant at $P<0.05$. Thus loss of production of the hexa-acylated form of the LPS had a modest effect on virulence in these otherwise attenuated strains.

\section{Influence of deletion of the IpxM gene on the protective potency of $Y$. pestis vaccine strains in a murine system}

All of the mice immunized with doses of the Russian vaccine strain $\mathrm{EV}$ between $10^{5}$ and $10^{9}$ c.f.u. and challenged with $7 \times 10^{5} \mathrm{LD}_{50}\left(4.2 \times 10^{6}\right.$ c.f.u. $)$ of wild-type, virulent $Y$. pestis strain 231 succumbed to infection, while $57 \%$ of the animals immunized with comparable doses of vaccine strain with the lp $x M$ gene deleted (EV $\Delta l p x M)$ survived. The calculated $\mathrm{ImD}_{50}$ values in immunized mice were $>10^{9}$ c.f.u. for the $\mathrm{EV}$ vaccine strain and $3.4 \times 10^{7}(95 \%$ $\left.\mathrm{CI}=8.6 \times 10^{6}-1.3 \times 10^{8}\right)$ c.f.u. for strain $\mathrm{EV} \Delta l_{p} x M$. Analysis of the mean survival time indicated that immunization with $\mathrm{EV} \Delta l p x M$ led to a 1.7 -fold increase in survival time in animals immunized with this strain when compared with those immunized with the parental vaccine strain $(P<0.05)$. Of note, when the challenge dose of the virulent $Y$. pestis strain 231 is reduced 20 times to $3.5 \times 10^{4} \mathrm{LD}_{50}$ $\left(2.1 \times 10^{5}\right.$ c.f.u. of $Y$. pestis strain 231$)$, as few as $2.4 \times 10^{3}$ c.f.u. $\left(95 \% \mathrm{CI}=9.0 \times 10^{2}-1.6 \times 10^{4}\right)$ of the vaccine strain EV were able to prevent death of $50 \%$ of the immunized animals (Anisimov, 1999b). Thus, the enhanced protective efficacy of the $\Delta l p x M$ mutant of the vaccine strain was only evident when a higher challenge inoculum of the virulent $Y$. pestis 231 was used.

\section{DISCUSSION}

$Y$. pestis easily overcomes the defence mechanisms of its animal hosts and readily proliferates in order to maintain the enzootic cycle essential to the organism's survival. To accomplish this, the organism must resist the innate immune response initiated by a variety of factors, including antimicrobial peptides and serum complement. The possibility to triumph over innate immunity response initiated by LPS-induced inflammatory cytokines is determined, in part, by the ability of the $\mathrm{V}$ antigen, which is a component of the type III secretion apparatus encoded on pCD, to provoke production of the anti-inflammatory cytokine, interleukin 10 (Brubaker, 2003). Production of other components of the type III secretion system that interfere with innate immune cellular factors and are cytotoxic for host cells are also essential for high-level virulence of $Y$. pestis (Cornelis, 2000). Resistance of Gram-negative bacteria to factors such as serum complement and antimicrobial peptides are generally related to carbohydrate components of the LPS, including both the monosaccharides present in the LPS oligosaccharide and 4-amino-Larabinose in the lipid A (Anisimov et al., 2005; Raetz \&

Table 4. Virulence of the $Y$. pestis strains

\begin{tabular}{|c|c|c|c|}
\hline Y. pestis strain & Application & $\mathrm{LD}_{50}$ c.f.u. $(95 \% \mathrm{CI})$ & Mean time to death (days)* \\
\hline 231 & Subcutaneous & $6(1-22)$ & $4.9 \pm 0.87(3,9)$ \\
\hline $231 \Delta l p x M$ & & $9(2-38)$ & $5.12 \pm 0.62(3,8)$ \\
\hline $\mathrm{EV} \Delta l p x M$ & & $2.9 \times 10^{8}\left(9.2 \times 10^{7}-2.9 \times 10^{9}\right)$ & $4.0 \pm 0.36(3,5)$ \\
\hline EV line NIIEG & Intraperitoneal with actinomycin $\mathrm{D}(10 \mu \mathrm{g}$ per mouse $)$ & $1.6 \times 10^{5}\left(4.0 \times 10^{4}-6.3 \times 10^{5}\right)$ & $3.38 \pm 0.77(1,6)$ \\
\hline $\mathrm{EV} \Delta l p x M$ & & $4.0 \times 10^{5}\left(1.0 \times 10^{5}-1.6 \times 10^{6}\right)$ & $3.18 \pm 0.64(1,5)$ \\
\hline $\mathrm{KM} 218 \Delta l p x M$ & & $4.0 \times 10^{6}\left(1.0 \times 10^{6}-1.6 \times 10^{7}\right)$ & $2.37 \pm 0.66(1,5)$ \\
\hline KIMD1 & & $1.0 \times 10^{5}\left(2.5 \times 10^{4}-4.0 \times 10^{5}\right)$ & $3.5 \pm 0.7(1,5)$ \\
\hline KIMD1 $1 p l p x M$ & & $1.6 \times 10^{6}\left(4.0 \times 10^{5}-6.3 \times 10^{6}\right)$ & $3.77 \pm 1.05(1,7)$ \\
\hline
\end{tabular}

${ }^{\star}$ The first and the last days of recorded deaths are given in parentheses. 
Whitfield, 2002). The potency of LPS in regard to induction of inflammatory cytokines is determined by the overall composition and individual fatty acid constituents found in the lipid A (Kawahara et al., 2002; Rebeil et al., 2004; Raetz \& Whitfield, 2002). A balanced production of variant forms of LPS in a pathogen such as $Y$. pestis that is dependent on the site and state of infection, and influenced by environmental conditions such as temperature (Kawahara et al., 2002; Knirel et al., 2005a; Rebeil et al., 2004), seems to have significant evolutionary value in the context of maintenance of the organism's natural life cycle. We have, therefore, set out to determine how the described chemical variations in the lipid A of the Y. pestis LPS contribute to virulence.

$Y$. pestis produces an overall less-acylated lipid A at $37{ }^{\circ} \mathrm{C}$ that elicits less intense inflammatory responses, which seems to be beneficial for the pathogen by preventing rapid host responses leading to quick elimination following infection (Kawahara et al., 2002). At temperatures below $26{ }^{\circ} \mathrm{C}$, the more potent hexa-acylated LPS form predominates. Although it has been postulated that this LPS isoform may be necessary for survival during infection of fleas, it was recently shown by Rebeil et al. (2006) that there is no difference in the ability of a wild-type or a $\Delta l p x M$ $\Delta l p x P Y$. pestis double mutant to survive in the flea digestive tract or to produce a transmissible infection. Therefore, at the present time a specific role for production of the hexa-acylated isoform of the LPS in the flea vector is not defined.

To determine the role of fatty-acid substitution on $Y$. pestis virulence in mammals, we generated a $\Delta l p x M$ mutant of the highly virulent $Y$. pestis strain 231, which was unable to incorporate the dodecanoyl group into lipid A. Cultures of the parent and mutant strains grown at $25{ }^{\circ} \mathrm{C}$ prior to infection showed no significant differences in their $\mathrm{LD}_{50}$ values. Thus, consistent with the findings of Rebeil et al. (2006) indicating there was no effect of LPS acylation on survival of $Y$. pestis in fleas, synthesis of the hexa-acylated LPS in arthropod vectors provided no advantage for $Y$. pestis during the initial stage of infection in the mammalian host. It remains to be determined if production of the hexa-acylated form of the LPS, which is increased at lower temperatures, is necessary for $Y$. pestis survival at the temperature of winter-hibernating rodents $\left(6^{\circ} \mathrm{C}\right)$.

In the case of attenuated $Y$. pestis strains, the $\Delta l p x M$ mutations resulted in a 2.5-16-fold reduction in residual virulence both in naïve and actinomycin D-sensitized animals. The same tenfold reduction in the toxicity of the $\mathrm{LPS}_{\triangle l p x M}$ preparation in actinomycin D-sensitized mice points towards the idea that, at least in the animals sensitized to LPS, the reduction of virulence of $\Delta l p x M$ mutants was due to a decrease of $\mathrm{LPS}_{\Delta l p x M}$ toxicity. This supposition was corroborated by the fact that the presence of a functional type III secretion system does not confer reliably increased virulence in actinomycin D-sensitized mice. In this assay the EV strain is only threefold more virulent than the KM218 strain, even though the latter is missing $\mathrm{pCD}$.

While it does not appear that production of the hexaacylated form of LPS is needed for virulence of wild-type $Y$. pestis, $\Delta l p x M$ mutants of other Gram-negative pathogens, such as E. coli (Somerville et al., 1996), Salmonella enterica serovar Typhimurium (Khan et al., 1998; Low et al., 1999; Sunshine et al., 1997), Haemophilus influenzae (Lee et al., 1995; Nichols et al., 1997), Shigella flexneri (D'Hauteville et al., 2002), Neisseria gonorrhoeae (Post et al., 2002), N. meningitidis (van der Ley et al., 2001) and Yersinia pseudotuberculosis (Dentovskaya et al., 2006), have reduced virulence. As these strains are less virulent than $Y$. pestis, it seems that in the absence of high levels of virulence, such as that which occurs in the plague bacillus, the $l_{p} x M$ gene does contribute to the organism's overall fitness to cause serious infections. Along the same lines, it was recently shown that even though the S. enterica serovar Typhimurium $\Delta l_{p} x M$ mutant possesses less ability to induce production by dendritic cells of TNF- $\alpha$, interleukin- $1 \beta$ and nitric oxide synthase than the parental strain (Kalupahana et al., 2003), this effect was only seen at low multiplicities of infection $(\leqslant 0.5)$. Infections at multiplicities of 5.0 or higher did not show any difference in the endotoxic properties of the two strains (Kalupahana et al., 2003). Thus, the $\Delta l p x M$ mutants of highly virulent strains that can initiate clinical disease following inoculation with a low number of bacterial cells still can produce an endotoxic shock even when synthesizing a less toxic form of LPS, while $\Delta l p x M$ mutants of less virulent bacteria are more dependent on synthesizing a LPS with high endotoxic properties.

Two types of plague vaccines, live attenuated and killed whole-cell vaccines, are currently available for use in humans. Both vaccines cause generally mild reactions but sometimes reactions can be severe in a significant percentage of individuals immunized (Naumov et al., 1992; Perry \& Fetherston, 1997). The overwhelming majority of these reactions (Marshall et al., 1974; Meyer et al., 1974a, b; Naumov et al., 1992; Reisman, 1970) are thought to be due to the bacterial endotoxin (Dmitrovskii, 1994; Galanos \& Freudenberg, 1993; Morrison \& Rayn, 1987; Raetz \& Whitfield, 2002; van Amersfoort et al., 2003; van der Poll \& van Deventer, 1999). Given that the Y. pestis LPS does not elicit protective immunity (Feodorova et al., 1999; Prior et al., 2001) it is reasonable to minimize endotoxic components in plague vaccine preparations. To this end, a number of LPS-free subunit and naked DNA candidate vaccines have been reported to be relatively nonreactogenic. These subunit and DNA vaccines incorporate the F1 capsular and the LcrV (or simply the V) antigens or their genes, and they can provide significant protection against experimental plague infections (Titball \& Williamson, 2001). However, since F1 capsule-negative $Y$. pestis strains have been recovered from at least one case of human infection and there is serological diversity in the $\mathrm{V}$ antigen, the current subunit vaccines under evaluation may 
not be sufficiently comprehensive, particularly when considering that the $Y$. pestis strains found in North and South America are clonally derived from a single importation in the early 20th century, whereas in endemic plague foci in Russia and Asia there is considerably greater antigenic and genetic diversity (Anisimov et al., 2004). While immunization with the live attenuated $Y$. pestis strain EV induces good protection against isolates with different antigenic compositions (Anisimov, 1999b) it is unlikely that one could generate viable LPS-free $Y$. pestis cells (Raetz \& Whitfield, 2002; Rietschel et al., 1994). However, by genetically manipulating the organism to only synthesize low-toxicity lipid A structures, it might be possible to produce a less reactogenic vaccine in an attenuated strain (van der Ley et al., 2001).

In the countries of the former Soviet Union, live-vaccinecontaining organisms grown at $28{ }^{\circ} \mathrm{C}$ that synthesize the hexa-acylated LPS are used for human immunization. This is due to the observation that $Y$. pestis cells grown at $28{ }^{\circ} \mathrm{C}$ are more viable and survive long-term storage better (Naumov et al., 1992). However, growth at $28{ }^{\circ} \mathrm{C}$ decreases expression of the F1 antigen, although this did not apparently affect protection, as there were no differences observed in this parameter comparing individuals immunized with $Y$. pestis vaccine strain $\mathrm{EV}$ grown at $37{ }^{\circ} \mathrm{C}$ compared with that grown at $28{ }^{\circ} \mathrm{C}$ (Russell et al., 1995; Sheremet et al., 1987). Importantly, if deleting the lpxM gene renders the vaccine strain less reactogenic and more immunogenic, as was shown here in the mouse studies, this might be useful for producing an improved live $Y$. pestis vaccine strain for human use, as long as the differences in specificity of human and mouse LPS receptors (Delude et al., 1995; Golenbock et al., 1991) do not impact the decreased reactogenicity of the $\Delta l p x M$ mutant of $Y$. pestis in humans. Any of the attenuated $Y$. pestis strains showing high protective potency, including Pgm ${ }^{-}$(Perry \& Fetherston, 1997), $\Delta$ dam (Robinson et al., 2005) and $\Delta p c m$ (Flashner et al., 2004) mutants, may be used for further $\Delta l p x M$ knockout. Nevertheless, further work is required to construct a $\Delta l p x M$ vaccine candidate strain lacking antibiotic resistance for future preclinical trials.

\section{ACKNOWLEDGEMENTS}

Research performed within the framework of the International Science and Technology Center (ISTC) partner project no. 1197 was supported by the Cooperative Threat Reduction programme of the US Department of Defence (ISTC partner). Research was also supported by the Russian Ministry for Industry, Science and Technology contract no. 43.600.1.4.0031, Russian Basic Research Foundation grants 03-04-48067 and 06-04-49280, German Research Foundation grant LI-448-1 and US National Institutes of Health grant AI AI46706-06.

Different parts of this work were presented at: the Scientific Conference on Basic and Applied Research in Medicine, 5-12 October 2003 , in Lautraki, Greece; the INTAS Strategic Workshop, Bacterial Glycoconjugates in Prevention and Diagnostics of Emerging Pathogens, 3rd
German-Polish-Russian Meeting on Bacterial Carbohydrates, 6-9 October 2004, in Wroclaw, Poland; the 6th Intergovernmental Scientific and Practical Conference of the Community of Independent States, Problems of Biosafety and Bioterrorism Counteraction at the Modern Conditions, 13-14 September 2005, in Volgograd, Russia; the Jubilee Scientific and Practical Conference devoted to 110th Anniversary of the Chair of Infectious Diseases of the S. M. Kirov Military Medical Academy, 22-24 March 2006, in St. Petersburg, Russia; and the 2006 NIAD Research Conference, 24-30 June, 2006, in Opatija, Croatia.

\section{REFERENCES}

Alexander, C. \& Rietschel, E. T. (2001). Bacterial lipopolysaccharides and innate immunity. J Endotoxin Res 7, 167-202.

Anisimov, A. P. (1999a). Factors providing the blocking activity of Yersinia pestis. Mol Gen Mikrobiol Virusol 4, 11-15.

Anisimov, A. P. (1999b). Molecular genetic mechanisms of the formation and functional significance of the capsule of Yersinia pestis. $\mathrm{ScD}$ thesis, Russian Research Anti-Plague Institute 'Microbe', Saratov, Russia.

Anisimov, A. P. (2002a). Factors of Yersinia pestis providing circulation and persistence of plague pathogen in ecosystems of natural foci. Communication 2. Mol Gen Mikrobiol Virusol 4, 3-11.

Anisimov, A. P. (2002b). Yersinia pestis factors, assuring circulation and maintenance of the plague pathogen in natural foci ecosystems. Report 1. Mol Gen Mikrobiol Virusol 3, 3-23.

Anisimov, A. P., Lindler, L. E. \& Pier, G. B. (2004). Intraspecific diversity of Yersinia pestis. Clin Microbiol Rev 17, 434-464.

Anisimov, A. P., Dentovskaya, S. V., Titareva, G. M., Bakhteeva, I. V., Shaikhutdinova, R. Z., Balakhonov, S. V., Lindner, B., Kocharova, N. A., Senchenkova, S. N. \& other authors (2005). Intraspecies and temperature-dependent variations in susceptibility of Yersinia pestis to bactericidal action of serum and polymyxin B. Infect Immun 73, 7324-7331.

Ashmarin, I. P. \& Vorob'ov, A. A. (1962). Statistical Methods in Microbiological Research. Leningrad: State Press of Medical Literature.

Aussel, L., Thérisod, H., Karibian, D., Perry, M. B., Bruneteau, M. \& Caroff, M. (2000). Novel variation of lipid A structures in strains of different Yersinia species. FEBS Lett 465, 87-92.

Brown, D. E. \& Morrison, D. C. (1982). Possible alteration of normal mechanisms of endotoxin toxicity in vivo by actinomycin D. J Infect Dis 146, 746-750.

Brozek, K. A. \& Raetz, C. R. H. (1990). Biosynthesis of lipid A in Escherichia coli. Acyl carrier protein-dependent incorporation of laurate and myristate. J Biol Chem 265, 15410-15417.

Brubaker, R. R. (1991). Factors promoting acute and chronic disease caused by yersiniae. Clin Microbiol Rev 4, 309-324.

Brubaker, R. R. (2003). Interleukin-10 and inhibition of innate immunity to Yersiniae: roles of Yops and LcrV (V antigen). Infect Immun 71, 3673-3681.

Brygoo, E. R. \& Rajenison, S. (1973). Technical improvement of the experimental diagnosis of plague. Use of mice sensitized by cyclophosphamide. Bull Soc Pathol Exot Filiales 66, 255-257.

Butler, T. (1989). The black death past and present. 1. Plague in the 1980s. Trans $R$ Soc Trop Med Hyg 83, 458-460.

Clementz, T., Zhou, Z. \& Raetz, C. R. H. (1997). Function of the Escherichia coli $m s b B$ gene, a multicopy suppressor of htrB knockouts, in the acylation of lipid A. J Biol Chem 272, 10353-10360. 
Cornelis, G. R. (2000). Molecular and cell biology aspects of plague. Proc Natl Acad Sci U S A 97, 8778-8783.

Das, U. N. (2000). Critical advances in septicemia and septic shock. Crit Care 4, 290-296.

Delude, R. L., Savedra, R., Zhao, H., Jr, Thieringer, R., Yamamoto, S., Fenton, M. J. \& Golenbock, D. T. (1995). CD14 enhances cellular responses to endotoxin without imparting ligand-specific recognition. Proc Natl Acad Sci U S A 92, 9288-9292.

Dentovskaya, S. V., Shaikhutdinova, R. Z., Knirel, Y. A., Ivanov, S. A. \& Anisimov, A. P. (2006). Construction of attenuated vaccine strains of Gram-negative bacteria. Mol Gen Mikrobiol Virusol 2, 3-8.

D'Hauteville, H., Khan, S., Maskell, D. J., Kussak, A., Weintraub, A., Mathison, J., Ulevitch, R. J., Wuscher, N., Parsot, C. \& Sansonetti, P. J. (2002). Two $m s b B$ genes encoding maximal acylation of lipid a are required for invasive Shigella flexneri to mediate inflammatory rupture and destruction of the intestinal epithelium. I Immunol 168, 5240-5251.

Dmitrovskii, V. G. (1994). Toxic component of pathogenesis of plague infectious process: infective toxic shock. In Prophylaxis and Means of Prevention of Plague, pp. 15-16. Edited by V. M. Stepanov. Almaty: Scientific-Manufacturing Association of the Plague-Control Establishments.

Donnenberg, M. S. \& Kaper, J. B. (1991). Construction of an eae deletion mutant of enteropathogenic Escherichia coli by using a positive-selection suicide vector. Infect Immun 59, 4310-4317.

Feodorova, V. A. \& Golova, A. B. (2005). Antigenic and phenotypic modifications of Yersinia pestis under calcium and glucose concentrations simulating the mammalian bloodstream environment. J Med Microbiol 54, 435-441.

Feodorova, V. A., Devdariani, Z. L. \& Nazarova, L. S. (1999). Adjuvant effect of anti-idiotypic antibodies to Yersinia pestis lipopolysaccharide. J Med Microbiol 48, 751-756.

Flashner, Y., Mamroud, E., Tidhar, A., Ber, R., Aftalion, M., Gur, D., Lazar, S., Zvi, A., Bino, T. \& other authors (2004). Generation of Yersinia pestis attenuated strains by signature-tagged mutagenesis in search of novel vaccine candidates. Infect Immun 72, 908-915.

Galanos, C. \& Freudenberg, M. A. (1993). Mechanisms of endotoxin shock and endotoxin hypersensitivity. Immunobiology 187, 346-356.

Galanos, C., Lüderitz, O. \& Westphal, O. (1969). A new method for the extraction of R lipopolysaccharides. Eur J Biochem 9, 245-249.

Galanos, C., Freudenberg, M. A. \& Reutter, W. (1979). Galactosamine-induced sensitization to the lethal effects of endotoxin. Proc Natl Acad Sci U S A 76, 5939-5943.

Golenbock, D. T., Hampton, R. Y., Qureshi, N., Takayama, K. \& Raetz, C. R. H. (1991). Lipid A-like molecules that antagonize the effects of endotoxins on human monocytes. J Biol Chem 266, 19490-19498.

Gremyakova, T. A., Vinogradov, E. V., Lindner, B., Kocharova, N. A., Senchenkova, S. N., Shashkov, A. S., Knirel, Y. A., Holst, O., Shaikhutdinova, R. Z. \& Anisimov, A. P. (2003). The core structure of the lipopolysaccharide of Yersinia pestis strain KM218. Influence of growth temperature. Adv Exp Med Biol 529, 229-231.

Higuchi, K. \& Smith, J. L. (1961). Studies on the nutrition and physiology of Pasteurella pestis. IV. A differential plating medium for the estimation of the mutation rate to avirulence. J Bacteriol $\mathbf{8 1}$, 605-608.

Hinnebusch, B. J. (2003). Transmission factors: Yersinia pestis genes required to infect the flea vector of plague. Adv Exp Med Biol 529, $55-62$.

Hinnebusch, B. J. (2004). The evolution of flea-borne transmission in Yersinia pestis. In Yersinia Molecular and Cellular Biology, pp. 49-73.
Edited by E. Carniel \& B. J. Hinnebusch. Wymondham: Horizon Bioscience.

Hitchen, P. G., Prior, J. L., Oyston, P. C., Panico, M., Wren, B. W., Titball, R. W., Morris, H. R. \& Dell, A. (2002). Structural characterization of lipo-oligosaccharide (LOS) from Yersinia pestis: regulation of LOS structure by the PhoPQ system. Mol Microbiol 44, 1637-1650.

Jackson, S. \& Burrows, T. W. (1956). The virulence-enhancing effect of iron on non-pigmented mutants of virulent strains of Pasteurella pestis. Br J Exp Pathol 37, 577-583.

Kalupahana, R., Emilianus, A. R., Maskell, D. \& Blacklaws, B. (2003). Salmonella enterica serovar Typhimurium expressing mutant lipid A with decreased endotoxicity causes maturation of murine dendritic cells. Infect Immun 71, 6132-6140.

Kawahara, K., Tsukano, H., Watanabe, H., Lindner, B. \& Matsuura, M. (2002). Modification of the structure and activity of lipid A in Yersinia pestis lipopolysaccharide by growth temperature. Infect Immun 70, 4092-4098.

Khan, S. A., Everest, P., Servos, S., Foxwell, N., Zähringer, U., Brade, H., Rietschel, E. T., Dougan, G., Charles, I. G. \& Maskell, D. J. (1998). A lethal role for lipid A in Salmonella infections. Mol Microbiol 29, 571-579.

Knirel, Y. A., Lindner, B., Vinogradov, E. V., Kocharova, N. A., Senchenkova, S. N., Shaikhutdinova, R. Z., Dentovskaya, S. V., Fursova, N. K., Bakhteeva, I. V. \& other authors (2005a). Temperature-dependent variations and intraspecies diversity of the structure of the lipopolysaccharide of Yersinia pestis. Biochemistry 44, 1731-1743.

Knirel, Y. A., Lindner, B., Vinogradov, E. V., Kocharova, N. A., Senchenkova, S. N., Shaikhutdinova, R. Z., Holst, O., Pier, G. B. \& Anisimov, A. P. (2005b). Cold temperature-induced modifications to the composition and structure of the lipopolysaccharide of Yersinia pestis. Carbohydr Res 340, 1625-1630.

Lee, N. G., Sunshine, M. G., Engstrom, J. J., Gibson, B. W. \& Apicella, M. A. (1995). Mutation of the htrB locus of Haemophilus influenzae nontypable strain 2019 is associated with modifications of lipid A and phosphorylation of the lipo-oligosaccharide. J Biol Chem 270, 27151-27159.

Lorange, E. A., Race, B. L., Sebbane, F. \& Hinnebusch, B. J. (2005). Poor vector competence of fleas and the evolution of hypervirulence in Yersinia pestis. J Infect Dis 191, 1907-1912.

Low, K. B., Ittensohn, M., Le, T., Platt, J., Sodi, S., Amoss, M., Ash, O., Carmichael, E., Chakraborty, A. \& other authors (1999). Lipid A mutant Salmonella with suppressed virulence and TNF $\alpha$ induction retain tumor-targeting in vivo. Nat Biotechnol 17, 37-41.

Marshall, J. D. J., Bartelloni, P. J., Cavanaugh, D. C., Kadull, P. J. \& Meyer, K. F. (1974). Plague immunization. II. Relation of adverse clinical reactions to multiple immunizations with killed vaccine. $J$ Infect Dis 129, S19-S25.

Meyer, K. F., Cavanaugh, D. C., Bartelloni, P. J. \& Marshall, J. D., Jr (1974a). Plague immunization. I. Past and present trends. J Infect Dis 129, S13-S18.

Meyer, K. F., Smith, G., Foster, L. E., Marshall, J. D., Jr \& Cavanaugh, D. C. (1974b). Plague immunization. IV. Clinical reactions and serologic response to inoculations of Haffekine and freeze-dried plague vaccine. $J$ Infect Dis 129, S30-S36.

Miller, J. H. (1972). Experiments in Molecular Genetics. Cold Spring Harbor, NY: Cold Spring Harbor Laboratory.

Morrison, D. C. \& Rayn, D. L. (1987). Endotoxins and disease mechanisms. Annu Rev Med 38, 417-432.

Naumov, A. V., Ledvanov, M. Yu. \& Drozdov, I. G. (1992). Plague Immunology. Saratov, Russia: Russian Research Anti-Plague Institute 'Microbe'. 
Nichols, W. A., Raetz, C. R. H., Clementz, T., Smith, A. L., Hanson, J. A., Ketterer, M. R., Sunshine, M. \& Apicella, M. A. (1997). htrB of Haemophilus influenzae: determination of biochemical activity and effects on virulence and lipooligosaccharide toxicity. J Endotoxin Res 4, 163-172.

Parkhill, J., Wren, B. W., Thomson, N. R., Titball, R. W., Holden, M. T., Prentice, M. B., Sebaihia, M., James, K. D., Churcher, C. \& other authors (2001). Genome sequence of Yersinia pestis, the causative agent of plague. Nature 413, 523-527.

Perry, R. D. (2003). A plague of fleas - survival and transmission of Yersinia pestis. ASM News 69, 336-340.

Perry, R. D. \& Fetherston, J. D. (1997). Yersinia pestis - etiologic agent of plague. Clin Microbiol Rev 10, 35-66.

Post, D. M. B., Phillips, N. J., Shao, J. Q., Entz, D. D., Gibson, B. W. \& Apicella, M. A. (2002). Intracellular survival of Neisseria gonorrhoeae in male urethral epithelial cells: importance of a hexaacyl lipid A. Infect Immun 70, 909-920.

Prior, J. L., Hitchen, P. G., Williamson, D. E., Reason, A. J., Morris, H. R., Dell, A., Wren, B. W. \& Titball, R. W. (2001). Characterization of the lipopolysaccharide of Yersinia pestis. Microb Pathog 30, 49-57.

Protsenko, O. A., Anisimov, P. I., Mozharov, O. T., Konnov, N. P., Popov, Y. A. \& Kokushkin, A. M. (1983). Detection and characterization of Yersinia pestis plasmids determining pesticin I, fraction I antigen and 'mouse' toxin synthesis. Sov Genet 19, 838-846.

Raetz, C. R. H. \& Whitfield, C. (2002). Lipooligosaccharide endotoxins. Annu Rev Biochem 71, 635-700.

Rebeil, R., Ernst, R. K., Gowen, B. B., Miller, S. I. \& Hinnebush, B. J. (2004). Variation in lipid A structure in the pathogenic yersiniae. $\mathrm{Mol}$ Microbiol 52, 1363-1373.

Rebeil, R., Ernst, R. K., Jarrett, C. O., Adams, K. N., Miller, S. I. \& Hinnebush, B. J. (2006). Characterization of late acyltransferase genes of Yersinia pestis and their role in temperature-dependent lipid A variation. J Bacteriol 188, 1381-1388.

Reeves, P. R., Hobbs, M., Valvano, M. A., Skurnik, M., Whitfield, C., Coplin, D., Kido, N., Klena, J., Maskell, D. \& other authors (1996). Bacterial polysaccharide synthesis and gene nomenclature. Trends Microbiol 4, 495-503.

Reisman, R. E. (1970). Allergic reactions due to plague vaccine. $J$ Allergy 46, 49-56.

Rietschel, E. T., Kirikae, T., Schade, F. U., Mamat, U., Schmidt, G., Löppnow, H., Ulmer, A. J., Zähringer, U., Seydel, U. \& other authors (1994). Bacterial endotoxin: molecular relationships of structure to activity and function. FASEB $J \mathbf{8}, 217-225$.

Robinson, V. L., Oyston, P. C. \& Titball, R. W. (2005). A dam mutant of Yersinia pestis is attenuated and induces protection against plague. FEMS Microbiol Lett 252, 251-256.

Russell, P., Eley, S. M., Hibbs, S. E., Manchee, R. J., Stagg, A. J. \& Titball, R. W. (1995). A comparison of plague vaccine, USP and EV76 vaccine induced protection against Yersinia pestis in a murine model. Vaccine 13, 1551-1556.

Seyberth, H. W., Schmidt-Gayk, H. \& Hackental, E. (1972). Toxicity, clearance and distribution of endotoxin in mice as influenced by actinomycin D, cycloheximide, $\alpha$-amanitin and lead acetate. Toxicon 10, 491-500.

Sheremet, O. V., Boshnakov, R. B., Kharabadzhakhian, G. D., Milanova, A. N., Kartasheva, L. D., Tomov, A. Ts. \& Kosovskii, V. K. (1987). Immunogenicity of Yersinia pestis grown on nutrient media at $28^{\circ}$ and $37^{\circ} \mathrm{C}$. Zh Mikrobiol Epidemiol Immunobiol 7, 63-68.

Simon, R., Priefer, U. \& Pühler, A. (1983). A broad host range mobilization system for in vivo genetic engineering: transposon mutagenesis in Gram negative bacteria. Biotechnology 1, 784-791.

Somerville, J. E., Jr, Cassiano, L., Bainbridge, B., Cunningham, M. D. \& Darveau, R. P. (1996). A novel Escherichia coli lipid A mutant that produces an anti-inflammatory lipopolysaccharide. J Clin Invest $\mathbf{9 7}$, 359-365.

Steeghs, L., Kuipers, B., Hamstra, H. J., Kersten, G., van Alphen, L. \& van der Ley, P. (1999). Immunogenicity of outer membrane proteins in a lipopolysaccharide-deficient mutant of Neisseria meningitidis: influence of adjuvants on the immune response. Infect Immun 67, 4988-4993.

Sunshine, M. G., Gibson, B. W., Engstrom, J. J., Nichols, W. A., Jones, B. D. \& Apicella, M. A. (1997). Mutation of the $h t r B$ gene in a virulent Salmonella typhimurium strain by intergeneric transduction: strain construction and phenotypic characterization. J Bacteriol 179, 5521-5533.

Titball, R. W. \& Williamson, E. D. (2001). Vaccination against bubonic and pneumonic plague. Vaccine 19, 4175-4184.

Tynianova, V. I., Ziuzina, V. P., Demidova, G. V., Sokolova, E. P., Pisanov, R. V., Bespalova, I. A., Borodina, T. N., Anisimov, B. I. \& Mishan'kin, B. N. (2003). Toxicity of the preparations of lipopolysaccharides isolated from $25^{\circ}$ and $37^{\circ}$ cultures of Yersinia pestis EV76. Biotekhnologiia (Mosc.) 6, 10-16.

van Amersfoort, E. S., van Berkel, T. J. C. \& Kuiper, J. (2003). Receptors, mediators, and mechanisms involved in bacterial sepsis and septic shock. Clin Microbiol Rev 16, 379-414.

van der Ley, P., Steeghs, L., Hamstra, H. J., Hove, J. T., Zomer, B. \& van Alphen, L. (2001). Modification of lipid A biosynthesis in Neisseria meningitidis l $p x L$ mutants: influence on lipopolysaccharide structure, toxicity, and adjuvant activity. Infect Immun 69, 5981-5990.

van der Poll, T. \& van Deventer, S. J. (1999). Cytokines and anticytokines in the pathogenesis of sepsis. Infect Dis Clin North Am 13, 413-426.

Vasil'eva, G. I., Doroshenko, E. P. \& Kiseleva, A. K. (1988). Changes in the 'latent' virulence of a vaccinal strain of Yersinia pestis multiplying within macrophages. Zh Mikrobiol Epidemiol Immunobiol 9, 63-66.

Vinogradov, E. V., Lindner, B., Kocharova, N. A., Senchenkova, S. N., Shashkov, A. S., Knirel, Y. A., Holst, O., Gremyakova, T. A., Shaikhutdinova, R. Z. \& Anisimov, A. P. (2002). The core structure of the lipopolysaccharide from the causative agent of plague, Yersinia pestis. Carbohydr Res 337, 775-777.

Yanisch-Perron, C., Vieira, J. \& Messing, J. (1985). Improved M13 phage cloning vectors and host strains: nucleotide sequences of the M13mp18 and pUC19 vectors. Gene 33, 103-119. 